\title{
LOW DENSITY CATTLE GRAZING ENHANCES ARTHROPOD DIVERSITY OF ABANDONED WETLAND
}

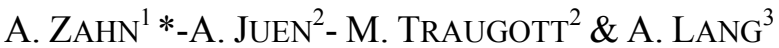 \\ ${ }^{1}$ Bund Naturschutz, Kreisgruppe Mühldorf, Graslitzerstr. 35, D-84478 Waldkraiburg \\ Tel. 0049 8638-3701Fax: 0049 8638-3701 \\ ${ }^{2}$ Institut of Ecology, Mountain Agriculture Research Unit, University of Innsbruck, \\ Technikerstraße 25, 6020 Innsbruck \\ ${ }^{3}$ Institute of Environmental Geosciences, University of Basel, Bernouillistr. 30, CH-4055 Basel \\ Tel. 0041612670477 Fax: 0041612670479 \\ e-mail:Andreas.Zahn@iiv.de
}

(Received $4^{\text {th }}$ Febr 2007 ; accepted $23^{\text {th }}$ May 2007)

\begin{abstract}
We studied the impact of low-density grazing on arthropod diversity in a small wetland (7 ha) in South Germany. The location was abandoned for 20 years, and was then grazed by Galloway for 4 to 5 years. The study site included the following habitat types: open land, a stand of alder (Alnus glutinosa), a stand of willows (Salix spec) and alder and a brookside. We counted higher species numbers on grazed than on neighbouring abandoned areas in ground beetles, rove beetles and spiders. Grazing explained a considerable amount of the variance of the species composition, and species typical for grazed plots could be identified. We found higher frequencies of insects during winter in Cirsium stems from grazed than from ungrazed areas. Grasshoppers and katydids (Saltatoria) of the grazed open land showed a general trend of increasing species number during the study period. Our findings show that low density grazing by cattle can favour habitat diversity even in small areas which enhances species numbers. However, special habitat types such as reed may need to be excluded from grazing in order to maintain the associated specific invertebrate community.
\end{abstract}

Key words: Grazing, arthropods, insects, diversity, wetland

\section{Introduction}

In many wetlands species richness and diversity depend on traditional land use patterns such as mowing and grazing (35). In Central Europe changing land use and intensification of agriculture have dramatically reduced the area of traditionally used wetlands (25), consequently many wetland species are highly endangered nowadays. Since long, mowing was regarded the most suitable conservation tool to preserve open wetland habitats $(5,28)$. However, sporadically mowing nowadays fully depends on financial support, while extensive grazing can be partly included in agricultural production and may be a less expensive tool for nature conservation (41). Especially in restoration projects for abandoned wetlands, where the re-establishment of mowing is very expensive, grazing comes more and more into practice $(3,15,19,38)$. Many studies investigated the fauna of dry habitats demonstrating that extensive grazing can be an adequate management method (e.g. 2, 8, 12, 24). In contrast, literature on the influence of low density grazing on the fauna of wetlands is scarce, in spite of the fact that grazing was the traditional land use in many wetlands in the past $(25,29)$. The few studies conducted about the fauna of grazed wetlands in Central Europe focused on medium sized and large areas ( $>30 \mathrm{ha})$. Regarding large areas, low density grazing is assumed to favour species diversity by the creation of diverse habitats $(1,11,18,27)$. However, approaches are needed in Central Europe for the management of small wetland areas (43). 
In our study we present a restoration project where ongoing succession of a small abandoned wetland (6 ha) should be prevented by low density cattle grazing. The project was launched by the Bund Naturschutz in Bayern. The aim is to protect the biodiversity of open landscapes by extensive farming practices (41).

We studied the influence of cattle grazing on vegetation and on animal populations. Our earlier results showed that the low density cattle grazing favours plant diversity and creates small scale habitat heterogeneity (42), enhances species richness of dung beetles (39), and reproduction success of endangered amphibians (43). The objective of this study are (i) determining the influence of grazing on the relative abundance of epigeic spiders and carabid as well as staphylinid beetles (ii) investigating changes in the species community in relation to grazing, (iii) analysing the long term reaction of grasshopper species on grazing, and (iv) comparing the densities of stem-infesting insects in grazed and abandoned plots.

\section{Study area}

The study area is located in South Germany (Oberbayern: $12^{\circ} 22^{\prime} 42^{\prime \prime}$ east, $48^{\circ} 10^{\prime} 05^{\prime \prime}$ north) and is about 7 ha in size. It includes a damp meadow and small woods (6 ha), which are grazed since 1996 except for a small area of the woodland which was not grazed before 1999. Additionally, an area of about 1 ha remained abandoned where natural succession could take place totally unaffected by grazing or other management activities, In the latter the samples for the ungrazed control were taken.

From April until November between six and nine Galloway cattle (one or two years old) roamed freely in the fenced area. Other management measures such as mowing in autumn were not applied.

\section{Methods}

\section{Community of spiders, ground beetles and rove beetles}

Spiders (Araneae), ground beetles (Carabidae) and rove beetles (Staphylinidae) were studied in grazed and adjacent abandoned (ungrazed) plots of the same habitat type. Pairs of sample plots (each $100 \mathrm{~m}^{2}$ ) were situated in the following habitats:

1) Open wetland; in the abandoned plot (1a) Urtica dioica, Phlaris arundinacea and Carex spec. were the dominating plant species, in the grazed plot (1b) these vegetation had been largely replaced by grasses (Poa spec), Mentha longifolia and Cirsium spec. The vegetation at $1 \mathrm{a}$ was on average higher and much denser than at $1 \mathrm{~b}$, bare ground without vegetation existed only at $1 \mathrm{~b}$.

2) Stand of Alnus glutinosa. In the ungrazed area (2a) Urtica dioica was dominating. The ground at the grazed plot (2b) was sparsely covered with grasses (Poa spec), and about $50 \%$ of the ground was without vegetation cover.

3) Stand of Salix caprea and Alnus glutinosa. At the ungrazed plot (3a) as well as at the grazed plot (3b), Urtica dioica, Galium aparine and Poa spec. were dominant, but the vegetation was less dense at $3 \mathrm{~b}$ because of trampling and grazing by Galloway cattle.

While at the grazed parts of the pairs 1 and 2 grazing started in 1996, plot 3 belonged to the woodland that was included in the grazed area (3b) in 1999. 
As an additional sample plot (4) we included an ungrazed reed at the brookside composed of Phragmites communis and Phalaris arundinacea at the banks of a small stream.

In 1999 and 2000 a set of 5 pitfalls (diameter $7 \mathrm{~cm}$ ) was installed at each plot and activated to catch epigeic invertebrates for 14 days in May, July and September. Trapping fluid was 5\% acetic acid and traps were covered with a non-transparent roof to avoid flooding by rain. Additionally, we used a sweeping net to collect spiders from the vegetation. Sampling was done at the end of each pitfall sampling periods and for each sample 100 net strikes were carried out. The arthropods were identified and differences in species number between grazed and ungrazed plots were tested with a t-test for paired samples, the tested combinations being the grazed-ungrazed pairs of each habitat type $(1-3)$.

Additionally CANOCO 4.5 (30) was used, to analyse the epigeic arthropod communities among the plots and to separate the influence of grazing from those of habitat characteristics and yearly changing environmental factors. Rare species (represented by less than 20 individuals) that are captured only by chance, were excluded from these analysis. This resulted in 20,14, and 12 ground beetle, rove beetle and spider species, respectively, which were included in the community analyses. To prevent taxa caught in high numbers from excessively influencing the ordinations, faunal counts were square-root transformed. Correspondence analysis (CA) was used to illustrate the major patterns in the community structure. Canonical correspondence analysis (CCA) and partial ordination was calculated to determine the influence of the grazing in relation to environmental conditions that differed among the habitats and the years by using categorical variables. We analysed Carabidae, Staphylinidae and Araneae separately and, additionally, all arthropod species together. Statistical significances were calculated by Monte Carlo permutation tests and taxa showing positive or negative correlation to grazing were identified by t-value biplots.

\section{The Grasshopper community}

Species numbers of grasshoppers were recorded visually on 8 grazed sample plots (each $100 \mathrm{~m}^{2}$ ) from 1996-2004. They were all located in grazed open wetland (1b), except one plot in a stand of Salix caprea, (see Zahn et al. 2003, for an overview over the vegetation of these sites). Each plot was searched for grasshoppers for 15 minutes once a year in late August. We did not distinguish between Chorthippus brunneus and Ch. biguttulus and between Tetrix undulata and T. subulata because it was difficult to determine single individuals without catching or acoustic methods.

\section{Influence of grazing on insects infesting Cirsium arvense}

To study the influence of Galloway grazing on insects infesting stems of plants, we sampled individuals of Cirsium arvense in the open wetland at 18 November 2002, in both the ungrazed (1a) and the grazed (1b) part. We distinguished between damaged and undamaged stems. Each sample consisted of 25 steams. As damaged we defined broken branches, open stems and partly browsed parts of the plant. The Cirsium - stems were spliced in the lab and searched for hibernating insects or signs of insect infestation (faeces, holes). 


\section{Results}

\section{Spiders and beetles in grazed and ungrazed areas}

Altogether, 65 species of Carabidae were recorded. Of these 9 (14\%) are considered as endangered species in the red data book of Bavaria and $6(9 \%)$ in the red data book of Germany (Tab. 2, appendix ). On average, numbers of carabid species were higher in plots grazed by Galloway cattle (44 species) compared to the ungrazed ones (38 species $)(\mathrm{p}=0.01$, habitats pooled, $\mathrm{df}=2$, t-test, Fig. 1). Grazed plots were characterized by the occurrence and/or high activity densities of species preferring moist and/or sunny environmental conditions such as Elaphrus cupreus, Dyschirius globosus, Acupalpis flavicollis, Oodes helopioides or Poecilus spp. (Tab 2, appendix.). The pitfall traps in the reed yielded the highest number of species recorded at one plot, i.e. 39 species (Fig. 1). Agonum micans, A. thoreyi and several species of the genus Bembidion, which are endangered and known for their special adaptations to survive in this type of habitat, were found exclusively at this site.

In total, 111 rove beetles species were recorded including four (4\%) endangered species of the Bavarian red data book. Overall species numbers were again higher at the grazed samples plots than on ungrazed ones (73 and 47 species in grazed and ungrazed plots, respectively). However, in one of the three pairs of plots, the Salix-Alnus stand $(3 \mathrm{a} / \mathrm{b})$, we found more species at the abandoned site -(Fig.1). At the brookside (reed) 51 species were captured. Of four red list species one was found in all habitats, one in the reed only, one at grazed plots only and at ungrazed plots only (Tab. 2, appendix ).

Altogether, 90 species of spiders were recorded of which 72 and 57 species were found in grazed and ungrazed plots, respectively. Only 27 species were captured in the reed, i.e. the ungrazed reed contributed not as much to spider biodiversity as to beetle diversity (Tab. 2, appendix). Two species (2\%) are listed in the red data books of Bavaria and Germany (Tab. 2. appendix); both occurred in ungrazed habitats only, Donacochara speciosa in the reed, and Clubiona stagnatilis in the reed as well as in the ungrazed open wetland. In all grazed plots the numbers of spider species tended to be higher compared to the abandoned references $(\mathrm{p}=0.06$, habitats pooled, $\mathrm{df}=2, \mathrm{t}$-test, Fig. 1). Especially Pirata, Pardosa and Oedothorax species, which are known as hygrophilous and heliophilous showed higher activity densities in the grazed plots.

Twenty-five species of spiders, 10 species of ground beetles and 34 species of rove beetles occurred exclusively on grazed plots (Tab. 2., appendix). For ungrazed plots the respective numbers were 13, 7, and 10 for spiders, ground beetles, and rove beetles, respectively. The ungrazed reed was characterised by 5 species of spiders, 9 species of ground beetles and 28 species of rove beetles, which were found only in this habitat. 

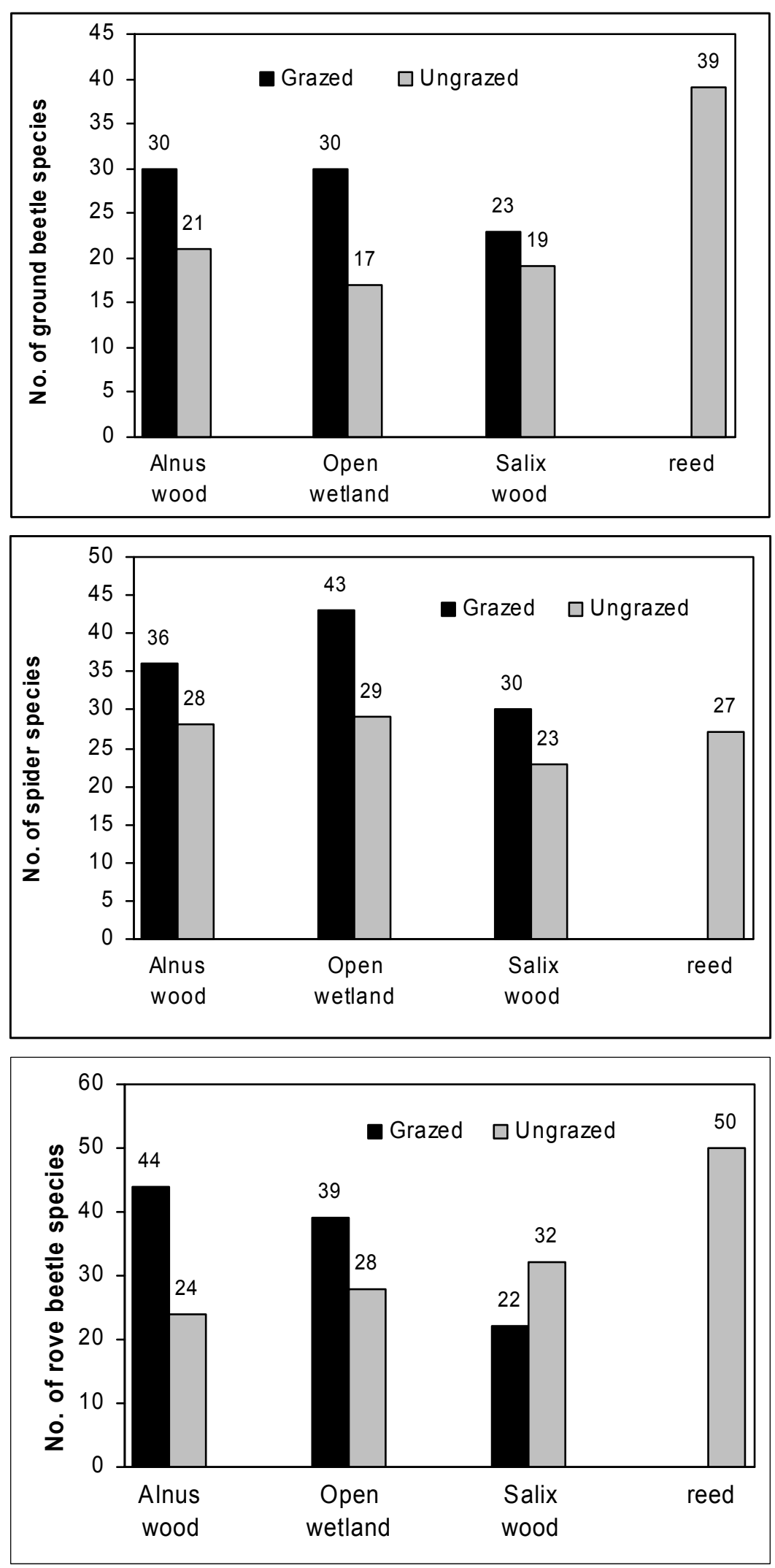

Figure 1. Impact of grazing on species numbers: Ground beetles, spiders and rove beetles on grazed and ungrazed habitats 


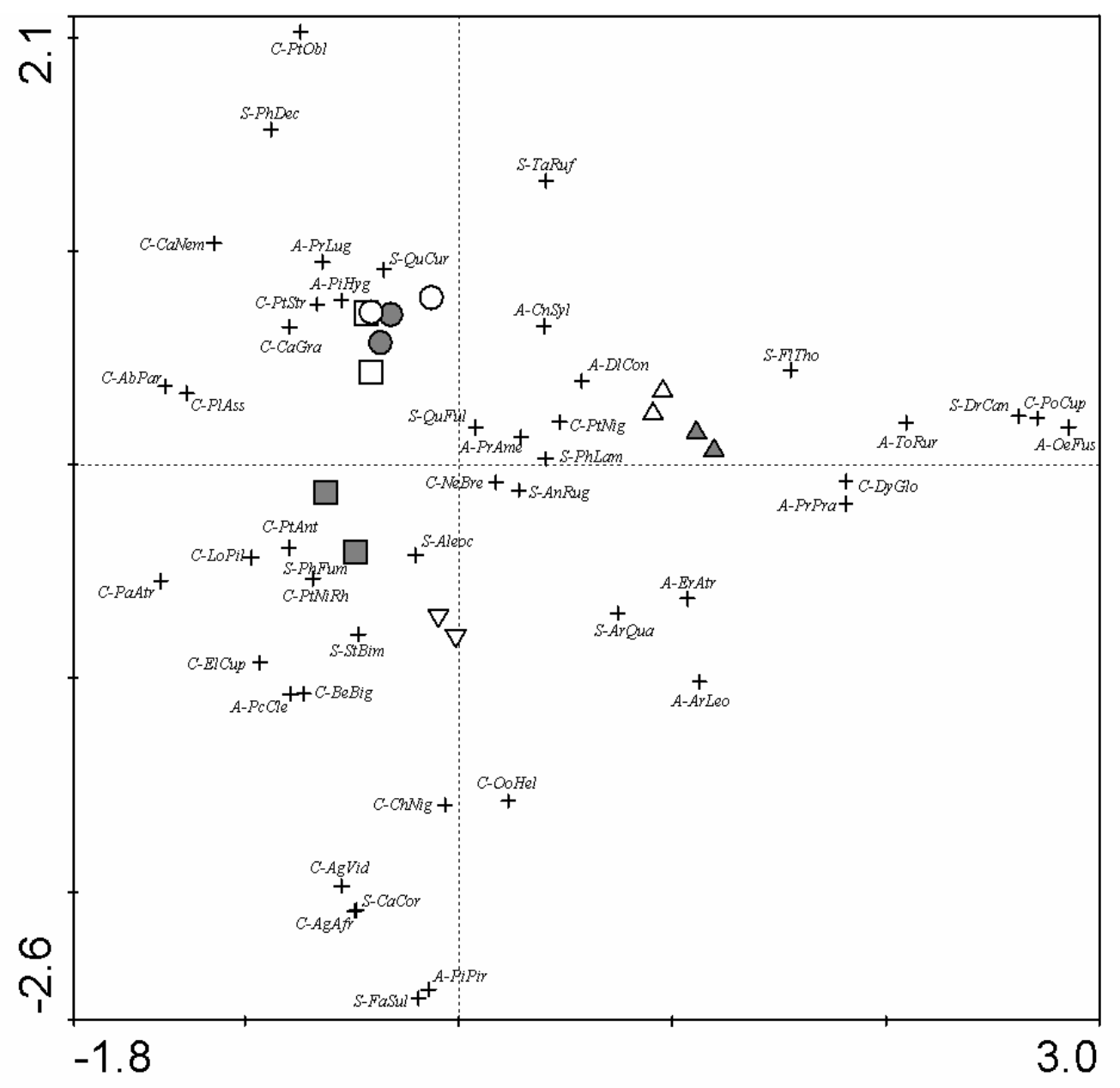

Figure 2. Fig. 2: Impact of grazing on single species. Given is the ordination of species in relation to the sample plots. Rectangles, circles, upright triangles, and turned round triangles represent stands of Alnus, stands of Salix and Alnus, open wetland, and reed, respectively. Filled symbols indicate grazed plots, while open symbols indicate ungrazed plots. In each case both years are shown. Species names are replaced by abbreviations including $C$-, $S$-, or $A$ - for Carabidae, Staphylinidae, or Araneae respectively followed by the first two letters of the genus and the first three letters of the species name. For the total name see Table 2 (Appendix).

An impact of grazing on the arthropod communities is also indicated by the ordination analyses. $6.3 \%$ of the total variance in the species composition can be explained by grazing (Tab. 1, Fig 2). This effect was more obvious in the ground beetle community $(7.6 \%)$ than in spiders $(4.0 \%)$ or rove beetles $(3.2 \%)$. Not surprisingly, habitat characteristics have been found to be the main factor determining the composition of the soil surface active arthropod community. Differences among the years were marginal (thus are not presented separately). According to a t-values biplot (Fig. 2) several species were significantly influenced by grazing: the ground beetles Nebria brevicollis, Poecilus cupreus, Patrobus atrorufus, Loricera pilicornis, Elaphrus cupreus, Pterostichus anthracinus, and Pterostichus nigrita/rhaeticus as well as the spiders Pardosa amentata, Erigone atra, Trochosa ruricola, and Pachygnatha clercki (A-PcCle) reacted positively on grazing; The relative abundances of these 11 species 
were higher on grazed plots than on ungrazed ones, irrespective of the influence of other environmental factors, habitat type and year. Negatively influenced by grazing were the rove beetles Tachinus signatus, Aleocharinae spp., Quedius fuliginosus, Quedius curtipennis, Philonthus decorus and Falagria thoracica, the ground beetles Carabus nemoralis, and Abax parallelepipedus, as well as the spiders Centromerus sylvaticus and Pardosa lugubris.

Table 1. Tab 1: Variance decomposition of the effect of grazing and other environmental factors on the epigeic arthropod community. Besides the percentage of total variance that can be explained ("all variables") or not explained ("unexplained") by the studied variables, the uniquely explained percentage of total variance by habitat differences and yearly changing environmental conditions ("habitat\&year") and by grazing ("grazing") is listed. "shared" gives the percentage of total variance that is explained by both ("habitat\&year" and "grazing")

$\begin{array}{lcccc} & \text { all Arthropods } & \text { Ground beetles } & \text { Rove beetles } & \text { Spiders } \\ \text { all variables } & \mathbf{4 5 . 7} & \mathbf{4 5 . 0} & \mathbf{4 4 . 5} & \mathbf{4 5 . 9} \\ \text { grazing } & \mathbf{6 . 3} & \mathbf{7 . 6} & \mathbf{3 . 2} & \mathbf{4 . 0} \\ \text { habitat\&year } & \mathbf{3 9 . 1} & \mathbf{3 7 . 9} & \mathbf{4 0 . 8} & \mathbf{4 0 . 8} \\ \text { shared } & \mathbf{0 . 3} & \mathbf{0 . 6} & \mathbf{0 . 5} & \mathbf{1 . 2} \\ \text { unexplained } & \mathbf{5 4 . 3} & \mathbf{5 5 . 0} & \mathbf{5 5 . 5} & \mathbf{5 4 . 1}\end{array}$

\section{Grasshoppers in grazed open wetland}

Grazing favoured the distribution of grasshopper species. The numbers of species on the sample plots increased during the first years and stayed on a higher level during the last years. (Fig 3). Since the beginning of the study in 1996, new species (Chorthippus parallelus and Chrysochraon dispar) were found in the area in 2004 only. Chorthippus albomarginatus was found sporadically outside the plots in 1996 but continuously on 2 plots during the last years of the study. Chorthippus brunneus/biguttulus and Gomphocerus rufus were found in increasing numbers until 1998, but slightly decreased again in the subsequent years. No tendency was obvious in Chorthippus dorsatus, Conocephalus discolor, Metrioptera roeseli, Pholidoptera griseoaptera, Tetrix undulata/subulata and Tettigonia cantans. In general, the mean number of single grasshopper species per site increased only in the beginning of the study. However, most species occupied more patches at the end of study indicating that the overall area of suitable habitats had increased.

\section{Stem-infesting insects}

We found the highest percentage of infested Cirsium plants in damaged stems from the grazed area and the lowest percentage in undamaged ones from the ungrazed plot (Fig. 4). However, the percentage of infested stems was also high in undamaged plants from the grazed area and only slightly lower in damaged plants from the ungrazed plot. The frequencies of infestation differed significantly (Chi-square $=11.8, \mathrm{p}<0.01$, $\mathrm{df}=$ $3)$. 


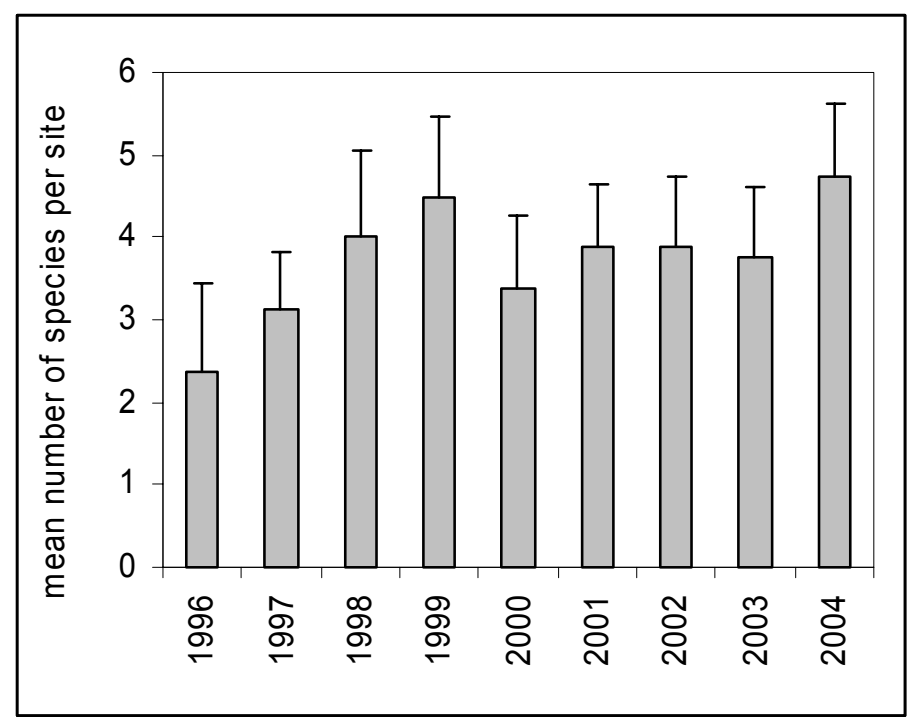

Figure 3. Number of Saltatoria species per sample plot (1996-2004), mean and standard error.

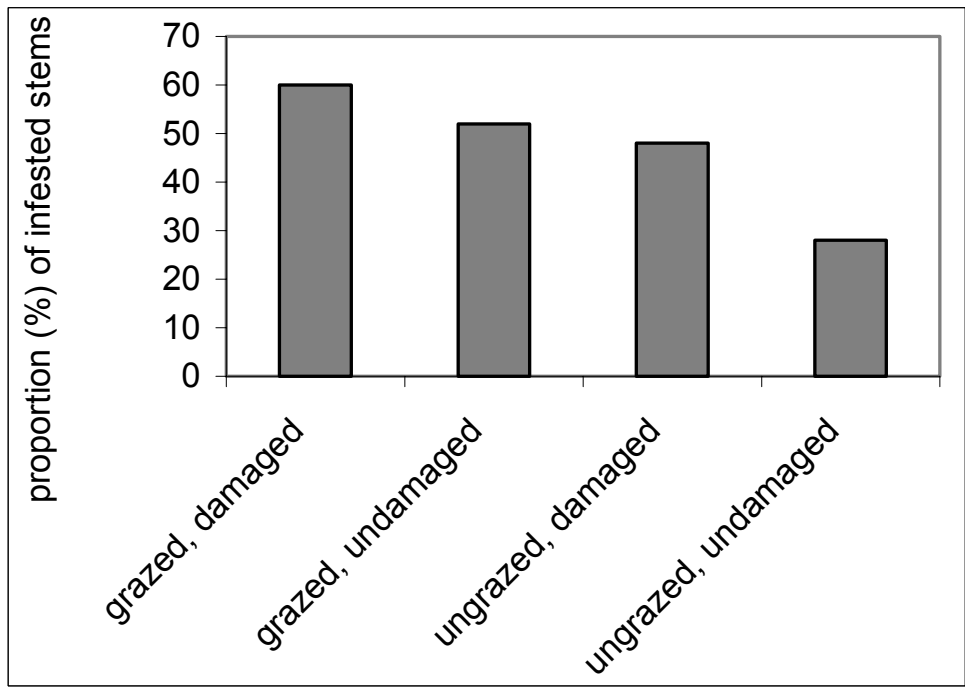

Figure 4. Percentage of stems infested by insects on neighbouring grazed and ungrazed plots. Each sample consisted of 25 stems. Damaged: Stem or twigs of a stem broken or bitten off.

\section{Discussion}

In general, higher species numbers of arthropods were found on grazed plots. Most likely the habitat mosaic created by the cattle was causing this result $(11,12,23,27)$. While some parts of the area are grazed intensively, other parts are hardly affected through grazing pressure. Some habitat types such as lawn-like, grass-dominated vegetation and bare ground exist only due to the presence of cattle, and are not present in the adjacent abandoned areas. High and low vegetation, bare ground and thick layers of organic material exist in the grazed areas in a low scale mosaic that remains quite stable over years (42). These predictable structural conditions favour species that depend on several habitat types, e.g. during different stages of their life cycle (26). 
However, biodiversity increased by grazing must not necessarily result in higher numbers of endangered species. Considering the "red book species" on the paired plots (grazed - abandoned), we found 9 species of spiders, rove and ground beetles on abandoned and 6 on grazed sites. Perhaps, immigration of endangered species into newly created habitats (the grazed area was abandoned before) is less likely than immigration of common species: many rare species depend on rare habitats (33), and therefore populations from which immigrants can come are scarce, too. Especially highly endangered wetland species can have very special habitat requirements (31), which may not be fulfilled in early restoration projects. And some species may not tolerate grazing at all (14).

Generally grazing favours xerothermophilous species which do not find suitable conditions in dense abandoned stands (34). However, trampling compressed the soil, especially at the woodland sample plots, which reduced drainage loss, thus favouring wet spots, which was reflected by the occurrence of hygrophilous carabids and spiders (sensu 20, 21). Wetland species, including some rare and endangered ones, were also typical for the sample plot in the reed, a habitat which could exist only because it was fenced and grazing pressure was excluded. This example demonstrates that low-density grazing does not enhance species richness in every case. Habitats, dominated by plant species such as reed that are preferably eaten by cattle, may even be destroyed, causing the loss of specific plant communities and the associated fauna (42).

In the case of the stem-infesting insects, damaged Cirsium individuals probably favour infestation by insects, and therefore the highest infestation rates are found on the grazed areas where plants are more often damaged. Additionally, the extend of damage of most Cirsium-plants is higher where the cattle moves. This may explain the difference in the infestation rate of damaged Cirsium on grazed an abandoned plots. However, even the undamaged stems are more frequently infested at the grazed plots. An explanation could be that these stems are not partly covered by the surrounding vegetation due to grazing which makes them more obvious as compared to ungrazed plots. In addition, the more open vegetation structure at grazed plots may offer a microclimate favouring insects.

The example of stem infesting insects illustrates, that grazing acts as a permanent disturbance in the studied ecosystem. Beneath the creation of new habitat types (e.g. bare ground, lawn, broken stems), disturbance generally decreases interspecific competition and may prevent the extinction of inferior competitors (24) which also favours species richness (7).

However, previous studies demonstrated that the intensity of disturbance is a key factor: Very intensively grazed areas show low biodiversity $(4,10,13,16,22)$. Van Wingerden et al. $(36,37)$ proposed a model in which moderate grazing intensity favours habitat diversity and species richness. If the grazing pressure is too high, the habitat diversity decreases again which reduces also the species numbers.

This indicates that management methods that reduce habitat diversity in extensively used grazing areas such as sporadic mowing (which is often practiced by farmers to reduce weeds) or short term high grazing pressure (which exists if the cattle is fenced for short periods on small areas e.g. to avoid selective grazing in endangered plant communities (28) have a negative influence on arthropod diversity. 
Acknowledgements. We are particularly grateful to Susanne Mommertz, Wolfgang Lorenz, Jadranka Mrzljak, Theo Blick for the determination of arthropods and to Christoph Chucholl, Christina Christoph and Rosa Kugler for help in the field.

\section{REFERENCES}

[1] Assmann, T., Falke, B. (1997): Bedeutung von Hudelandschaften aus tierökologischer und naturschutzfachlicher Sicht. - Schr.-R. f. Landschaftspfl. u. Natursch. 54: 129-144.

[2] Ausden, M., Treweek J. (1995): Graslands. - In: Sutherland W.J. \& Hill, D. A. (Hrsg), Managing habitats for conservationc (Cambridge University Press, Cambridge), 197-229.

[3] Barth, U., Gregor, T., Lutz, P., Niederbichler, C., Pusch, J. Wagner, A., Wagner I. (2000): Zur Bedeutung extensiv beweideter Nassstandorte für hochgradig bedrohte Blütenpflanzen und Moose. - Natur \& Landschaft 75 (7): 292-300.

[4] Bell, J., Philip, R, Wheater, C.P., Cullen, W. R. (2001): The implications of grassland and heathland management for the conservation of spider communities: a review. - J. Zool., Lond. 255, 377-387.

[5] Blab, J. (1986): Grundlagen des Bioptopschutzes für Tiere. - Schriftenreihe für Landschaftspflege und Naturschutz 24, Kilda Verlag, Greven, $257 \mathrm{~S}$

[6] Blick T., Muster, C.(2003): Rote Liste gefährdeter Spinnen (Arachnida: Araneae) Bayerns. - Schr.R- Bayer. Landesamt Umweltsch. 166: 308-321.

[7] Bokdam, J., Gleichmann, M..J. (2000): Effects of grazing by free-ranging cattle on vegetation dynamics in a continental north-west European heathland. - Journal of Applied Ecology 37: 415-431.

[8] Bornhold, G. (1991): Auswirkungen der Pflegemaßnahmen Mahd, Mulchen, Beweidung und Gehölzrückschnitt auf die Insektenordnungen Orthoptera, Heteroptera, Auchenorrhyncha und Coleoptera der Halbtrockenrasen im Raum Schlüchtern. - Marburger Entomologische Publikationen 2: 1-330.

[9] Bussler, H., Hofmann, G. (2003): Rote Liste gefährdeter Kurzflüglerartiger (Coleoptera Staphylinoidea) Bayerns. - Schr.R- Bayer. Landesamt Umweltsch. 166: 117-128.

[10] Dennis, P., Young, M.R., Howard, C.L., Gordon, I. J. (1997): The response of epigeal beetles (Col.: Carabidae, Staphylinidae) to varied grazing regimes on upland Nardus stricta grasslands. - Journal of Applied Ecology 34: 433-443.

[11] Elligsen, H. (1997): Die Tagfalter- und Widderchenfauna (Lepidoptera) eines Magerrasens der Vorkarpaten (Ukraine) unter besonderer Berücksichtigung der Habitatnutzung ausgewählter Arten. - Entomol. Z. 107 (8): 319-342.

[12] Elligsen, H., Beinlich, B., Plachter, H. (1997): Effects of large-scale cattle grazing on populations of Coenonympha glycerion and Lasiommata megera (Lepidoptera: Satyridae).- Journal of Insect Conservation 1: 13-23.

[13] Gibson, C.W.D., Hambler, C., Brown, V.K. (1992): Changes in spider (Araneae) assemblages in relation to succession and grazing management. - Journal of Applied Ecology 29: 132-142.

[14] Hermann G., Anthes N. (2004): Goldener Scheckenfalter. - Angewandte Landschaftsökologie 62: 311-314.

[15] Jilg, T. Elsässer, M., Briemle, G., Armbuster, M. (1999): Beweidung des Europareservats Federseeried (Württ./Deutschland) mit Hinterwälder- und Fleckvieh-Mutterkühen. Natur- und Kulturlandschaft 3: 264-272

[16] Kruess A., Tscharntke T. (2002): Grazing Intensity and the diversity of Grasshoppers, Butterflies, and Trap-Nesting Bees and Wasps. - Conservation Biology 16: 1570-1580.

[17] Lorenz, W.M.T. (2003): Rote Liste gefährdeter Lauf- und Sandlaufkäfer (Coleoptera Carabidae s.1.) Bayerns. - Schr.R- Bayer. Landesamt Umweltsch. 166: 102-111.

[18] Luick R. (2002): Möglichkeiten und Grenzen extensiver Weidesysteme mit besonderer Berücksichtigung des Feuchtgrünlandes. - Laufener Seminarbeiträge 1/02: 5-21. 
[19] Luick, R. (1995): Ein Modellprojekt zur extensiven Beweidung von Feuchtgrünland. Beiträge der Akademie für Natur- und Umweltschutz Baden - Württemberg 18: 77-86.

[20] Marggi, W.A. (1992): Faunistik der Sandlaufkäfer und Laufkäfer der Schweiz (Cicindellidae und Carabidae, Coleoptera). Teil 1, Text. - Documenta Faunistica Helvetiae 13. Centre Suisse de cartographie de la faune, Neuchâtel. 477 pp.

[21] Maurer, R., Hänggi, A. (1990): Katalog der schweizerischen Spinnen. Documenta Faunistica Helvetiae 12. Centre Suisse de cartographie de la faune, Neuchâtel. 412 pp.

[22] Nordheim, v. H. (1992): Auswirkungen unterschiedlicher Bewirtschaftungsmethoden auf die Wirbellosenfauna des Dauergrünlandes. - NNA-Berichte 4/92:13-26.

[23] Nyffeler, M. (1998): Stress im grünen Gras. Einfluss der Bewirtschaftung auf Wiesenspinnen. - Ornis 5: 4-9.

[24] Poethke H. J. (1997): Die Bedeutung von Störungen und Katastrophen für die ökologische Vielfalt. - Schr.R.f.Landschaftspfl.u.Natursch.54: 265-276.

[25] Radlmair, S., Plachter, H., Pfadenhauer J. (1999): Geschichte der landwirtschaftlichen Moornutzung im süddeutschen Alpenvorland. Ein Beitrag zur naturschutzfachlichen Leitbilddiskussion. - Natur und Landschaft 74 (3): 9198.

[26] Riecken, U., Finck, P., Klein, M., Schröder, E. (1998): Überlegungen zu alternativen Konzepten des Naturschutzes für den Erhalt und die Entwicklung von Offenlandbiotopen. - Natur und Landschaft 73: 261-270.

[27] Riecken, U., Klein, M., Schröder, E. (1997): Situation und Perspektive des extensiven Grünlands in Deutschland und Überlegungen $\mathrm{zu}$ alternativen Konzepten des Naturschutzes am Beispiel der Etablierung "halboffener Weidelandschaften". - Schr.-R. f. Landschaftspfl. u. Naturschutz 54: 7-23.

[28] Rosenthal, G., Hermann, G., Lederbogen, D. (2004a): Bedeutung der Offenhaltung der Landschaft für die Ziele des Arten und Biotopschutzes. Angewandte Landschaftsökologie 62: 34-44.

[29] Rosenthal, G., Zimmermann, B., Trautner, J. (2004b): Synthese. - Angewandte Landschaftsökologie 425-443.

[30] Ter Braak, C. J. F. \& Smilauer, P. (2002): CANOCO Reference Manual and CanoDraw for Windows User's Guide: Software for Canonical Community Ordination. Microcomputer Power (Ithaca, NY, USA), 500pp.

[31] Trauner, J., Hermann, G., Rietze, J. (2004): Weidewirkung auf Tierarten und zönosen. - Angewandte Landschaftsökologie 62: 275-285.

[32] Trautner J., Müller-Motzfeld, G., Bräunicke, M. (1998): Rote Liste der Sandlaufkäfer und Laufkäfer (Coleoptera: Cicindellidae et Carabidae). - Schr.R. Landschaftspfl. Natursch. 55: 159-167.

[33] Voith, H. (2003): Grundlagen und Bilanzen zur Roten Liste gefährdeter Tiere Bayerns. - Schr.R- Bayer. Landesamt Umweltsch. 166: 11-24.

[34] Walther, C. 1995: Untersuchungen zur Fauna regelmäßig beweideter Kalkmagerrasen. Beih. Veröff. Naturschutz Landschaftspflege Bad.-Württ. 83: 159-180

[35] Watkinson, A.R., Ormerod, S.J. (2001): Grasslands, grazing and biodiversity: editors' introduction. - Journal of AppliedEcology 38: 233-237.

[36] Wingerden, W.K.R.E., Kreveld, A.R., Bongers, W. (1992): Analyses of species composition and abundance of grasshoppers in natural and fertilized grassland. - J. Appl. Ent. 113: 138-152.

[37] Wingerden, W.K.R.E., Musters, J.C. M., Kleukers, R.M.J.C., Bongers, W., Biezen, J. B. (1991): The influence of cattle grazing intensity on grasshopper abundance. - Proc. Exper. \& Appl. Entomol. N.E. V. Amsterdam 2: 28-34. 
[38] Wittig, B., Urban, K., Hellberg, F. (2000): Pflegemaßnahmen zu Erhaltung und Wiederherstellung von Feuchtheiden. - Natur \& Landschaft 75 (12): 465-473.

[39] Zahn, A., Hirschberger, P. (2001): Die Dungkäferfauna von Rinder-Standweiden in Oberbayern. - Zeitschrift für Ökologie und Naturschutz 9: 219-224.

[40] Zahn, A., Lang, A., Meinl, M. (2001): Galloway Rinder als Landschaftsgestalter - Ein Naturschutzprojekt zur Pflege einer offenen Kulturlandschaft. - Natur- und Kulturlandschaft 4: 332-342.

[41] Zahn, A., Lang, A., Meinl, M., Schirlitz T. (2002): Die Beweidung einer Feuchtbrache mit Galloway-Rindern - Flora, Fauna und wirtschaftliche Aspekte einer kleinflächigen Standweide. - Laufener Seminarbeiträge 1/02: 35-45.

[42] Zahn, A., Meinl, M. \& Niedermeier, U. (2003): Auswirkungen extensiver Rinderbeweidung auf die Vegetation einer Feuchtbrache. Naturschutz und Landschaftsplanung 35 (6): 171-178.

[43] Zahn, A., Niedermeier, U. (2004): Zur Reproduktionsbiologie von Wechselkröte (Bufo viridis), Gelbbauchunke (Bombina variegata) und Laubfrosch (Hyla arborea) im Hinblick auf unterschiedliche Methoden des Habitatmanagements. - Zeitschrift für Feldherpetologie 11: 1-24.

Appendix: Tab. 2. Araneae, Carabidae and Staphylinidae recorded on grazed, ungrazed plots and in the reed along the brook. Species listed in the Red Data book of Bavaria and/or Germany are underlined (Lorenz 2003; Trautner et al. 1998; Bussler \& Hofmann 2003; Blick \& Muster 2003).

\begin{tabular}{|c|c|c|c|c|c|c|c|c|c|c|c|}
\hline Spiders & 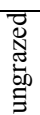 & 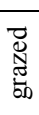 & 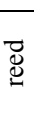 & Ground beetles & 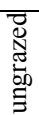 & 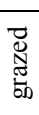 & $\underset{\circlearrowright}{巳}$ & Rove beetles & 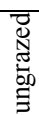 & $\begin{array}{l}\overrightarrow{\mathbb{N}} \\
\mathbb{\widetilde { N }} \\
\sigma_{0}\end{array}$ & ర્ల \\
\hline Achaearanea simulans & $\mathrm{x}$ & & & Abax parallelepipedus & $\mathrm{x}$ & $\mathrm{x}$ & $\mathrm{x}$ & Aleochara brevipennis & & $\mathrm{x}$ & $\mathrm{x}$ \\
\hline Aculepeira ceropegia & & $\mathrm{x}$ & & Acupalpus flavicollis & & $\mathrm{x}$ & $\mathrm{x}$ & Aleocharinae sp. & $\mathrm{x}$ & $\mathrm{x}$ & $\mathrm{x}$ \\
\hline Antistea elegans & & & $\mathrm{x}$ & Agonum afrum & & $\mathrm{x}$ & $\mathrm{x}$ & Aloconota insecta & & $\mathrm{x}$ & \\
\hline Araeoncus humilis & $\mathrm{x}$ & $\mathrm{x}$ & & Agonum fuliginosum & $\mathrm{x}$ & $\mathrm{x}$ & $\mathrm{x}$ & Anotylus mutator Lohse & $\mathrm{x}$ & & \\
\hline Araneus diadematus & $\mathrm{x}$ & $\mathrm{x}$ & & Agonum micans & & & $\mathrm{x}$ & Anotylus rugosus & $\mathrm{x}$ & $\mathrm{x}$ & $\mathrm{x}$ \\
\hline Araneus marmoreus & & $\mathrm{x}$ & & Agonum muelleri & & $\mathrm{x}$ & $\mathrm{x}$ & Anotylus sculpturatus & $\mathrm{x}$ & $\mathrm{x}$ & \\
\hline Araneus quadratus & $\mathrm{x}$ & & & Agonum sexpunctatum & $\mathrm{x}$ & $\mathrm{x}$ & $\mathrm{x}$ & Anotylus tetracarinatus & $\mathrm{x}$ & & \\
\hline Araniella cucurbitina & $\mathrm{x}$ & & & Agonum thoreyi & & & $\mathrm{x}$ & Arpedium quadrum & $\mathrm{x}$ & $\mathrm{x}$ & $\mathrm{x}$ \\
\hline Araniella sp. & & $\mathrm{x}$ & $\mathrm{x}$ & Agonum viduum & & $\mathrm{x}$ & $\mathrm{x}$ & Atheta ravilla $c f$. & & $\mathrm{x}$ & \\
\hline Arctosa leopardus & $\mathrm{x}$ & $\mathrm{x}$ & $\mathrm{x}$ & Amara aulica & $\mathrm{x}$ & $\mathrm{x}$ & & Bledius erraticus & $\mathrm{x}$ & & \\
\hline Argiope bruennichi & & $\mathrm{x}$ & & Amara communis & $\mathrm{x}$ & & & Bledius opacus & & $\mathrm{x}$ & \\
\hline Bathyphantes approximatus & & $\mathrm{x}$ & & Amara plebeja & & $\mathrm{x}$ & & Carpelimus arcuatus & & & $\mathrm{x}$ \\
\hline Bathyphantes gracilis & & $\mathrm{x}$ & $\mathrm{x}$ & Anisodactylus binotatus & $\mathrm{x}$ & $\mathrm{x}$ & & Carpelimus corticinus & & $\mathrm{x}$ & $\mathrm{x}$ \\
\hline Batyphantes nigrinus & & $\mathrm{x}$ & & $\begin{array}{l}\text { Asaphidion cf. } \\
\text { austriacum }\end{array}$ & & $\mathrm{x}$ & & Carpelimus rivularis & & & $\mathrm{x}$ \\
\hline Centromerita bicolor & & $\mathrm{x}$ & & Badister lacertosus & $\mathrm{x}$ & $\mathrm{x}$ & & Chilopora longitarsis & & $\mathrm{x}$ & \\
\hline Centromerus sylvaticus & $\mathrm{x}$ & $\mathrm{x}$ & $\mathrm{x}$ & Badister sodalis & $\mathrm{x}$ & $\mathrm{x}$ & $\mathrm{x}$ & Chilopora rubicunda & & & $\mathrm{x}$ \\
\hline Cercidia prominens & & $\mathrm{x}$ & & Bembidion articulatum & $\mathrm{x}$ & $\mathrm{x}$ & $\mathrm{x}$ & Deubelia picina & & & $\mathrm{x}$ \\
\hline Clubiona lutescens & $\mathrm{x}$ & $\mathrm{x}$ & & Bembidion biguttatum & & & $\mathrm{x}$ & Dexiogya corticina & $\mathrm{x}$ & & \\
\hline Clubiona phragmitis & & & $\mathrm{x}$ & Bembidion lampros & & & $\mathrm{x}$ & Drusilla canaliculata & $\mathrm{x}$ & $\mathrm{x}$ & $\mathrm{x}$ \\
\hline Clubiona stagnatilis & $\mathrm{x}$ & & $\mathrm{x}$ & Bembidion properans & & $\mathrm{x}$ & & Falagria sulcatula & & & $\mathrm{x}$ \\
\hline Coelotes terrestris & $\mathrm{x}$ & $\mathrm{x}$ & & Bembidion tetracolum & & $\mathrm{x}$ & $\mathrm{x}$ & Falagria thoracica & $\mathrm{x}$ & $\mathrm{x}$ & $\mathrm{x}$ \\
\hline Diaea dorsata & & $\mathrm{x}$ & & Blemus discus & & & $\mathrm{x}$ & Falagris sulcatula & & $\mathrm{x}$ & \\
\hline Dicymbium cf. brevisetosum & & $\mathrm{x}$ & & Carabus cancellatus & $\mathrm{x}$ & $\mathrm{x}$ & & Gabrius pennatus & & $\mathrm{x}$ & $\mathrm{x}$ \\
\hline Dicymbium tibiale & $\mathrm{x}$ & $\mathrm{x}$ & & Carabus coriaceus & $\mathrm{x}$ & & $\mathrm{x}$ & Gabrius subnigritulus & & $\mathrm{x}$ & \\
\hline Diplocephalus cristatus & $\mathrm{x}$ & $\mathrm{x}$ & & Carabus granulatus & $\mathrm{x}$ & $\mathrm{x}$ & $\mathrm{x}$ & Gabrius trossulus & $\mathrm{x}$ & $\mathrm{x}$ & $\mathrm{x}$ \\
\hline Diplocephalus latifrons & $\mathrm{x}$ & $\mathrm{x}$ & & Carabus hortensis & $\mathrm{x}$ & $\mathrm{x}$ & & Geostiba circellaris & & $\mathrm{x}$ & \\
\hline Diplostyla concolor & $\mathrm{x}$ & $\mathrm{x}$ & $\mathrm{x}$ & $\underline{\text { Carabus irregularis }}$ & $\mathrm{x}$ & & & Gyrohypnus scoticus & $\mathrm{x}$ & $\mathrm{x}$ & \\
\hline Dismodicus bifrons & & $\mathrm{x}$ & $\mathrm{x}$ & Carabus nemoralis & $\mathrm{x}$ & & & Hygropora cunctans $c f$. & $\mathrm{x}$ & & $\mathrm{x}$ \\
\hline$\underline{\text { Donacochara speciosa }}$ & & & $\mathrm{x}$ & $\underline{\text { Chlaenius nigricornis }}$ & $\mathrm{x}$ & $\mathrm{x}$ & $\mathrm{x}$ & $\begin{array}{l}\text { Hypostenus } \\
\text { cicindeloides }\end{array}$ & & $\mathrm{x}$ & \\
\hline Drapetisca socialis & & $\mathrm{x}$ & & Chlaenius vestitus & & & $\mathrm{x}$ & Ilyobates propinquus & $\mathrm{x}$ & $\mathrm{x}$ & \\
\hline
\end{tabular}




\begin{tabular}{|c|}
\hline Drassyllus pusillus \\
\hline Enoplognatha ovata \\
\hline Erigone atra \\
\hline Erigone dentipalpis \\
\hline Evarcha arcuata \\
\hline Evarchasp. \\
\hline Gnathonarium dentatum \\
\hline Helophora insignis \\
\hline Larinioides $s p$. \\
\hline Lepthyphantes cristatus \\
\hline Lepthyphantes pallidus \\
\hline Lepthyphantes tenuis \\
\hline Leptorhoptrum robustum \\
\hline Leptyphantes sp. \\
\hline Linyphia hortensis \\
\hline Linyphia triangularis \\
\hline Mangora acalypha \\
\hline Metellina cf. merianae \\
\hline Metellina mengei \\
\hline Metellina segmentata \\
\hline Micrargus herbigradus \\
\hline Misumenops tricuspidatus \\
\hline Neriene clathrata \\
\hline Neriene montana \\
\hline Neriene peltata \\
\hline Oedothorax agrestis \\
\hline Oedothorax fuscus \\
\hline Ozyptila praticola \\
\hline Ozyptila trux \\
\hline Pachygnatha clercki \\
\hline Pachygnatha listeri \\
\hline Paidiscura pallens \\
\hline Pardosa amentata \\
\hline Pardosa lugubris \\
\hline Pardosa palustris \\
\hline Pardosa prativaga \\
\hline Pardosa pullata \\
\hline Pardosa riparia \\
\hline Pelecopsis parallela \\
\hline Philodromus sp. \\
\hline Pirata hygrophilus \\
\hline Pirata latitans \\
\hline Pirata piraticus \\
\hline Pisaura mirabilis \\
\hline Porrhomma convexum \\
\hline Robertus lividus \\
\hline Robertus neglectus \\
\hline Singa hamata \\
\hline Tetragnatha extensa \\
\hline Tetragnatha montana \\
\hline Tetragnatha pinicola \\
\hline Theridion impressum \\
\hline Theridion varians \\
\hline Trematocephalus cristatus \\
\hline Trochosa ruricola \\
\hline
\end{tabular}

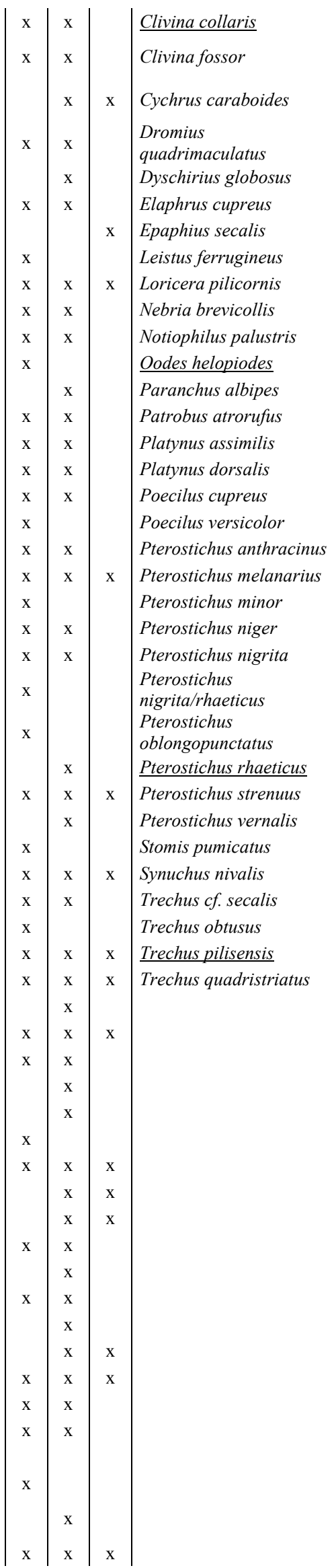

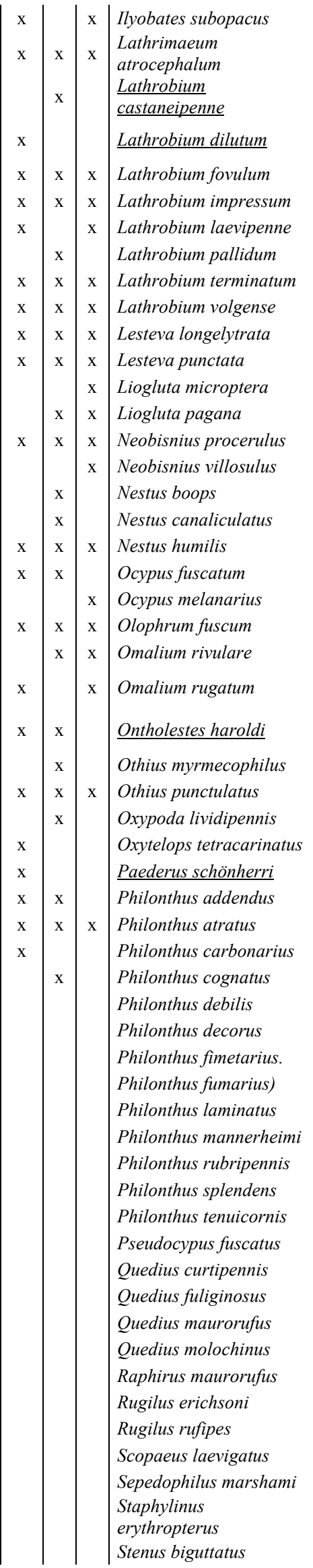




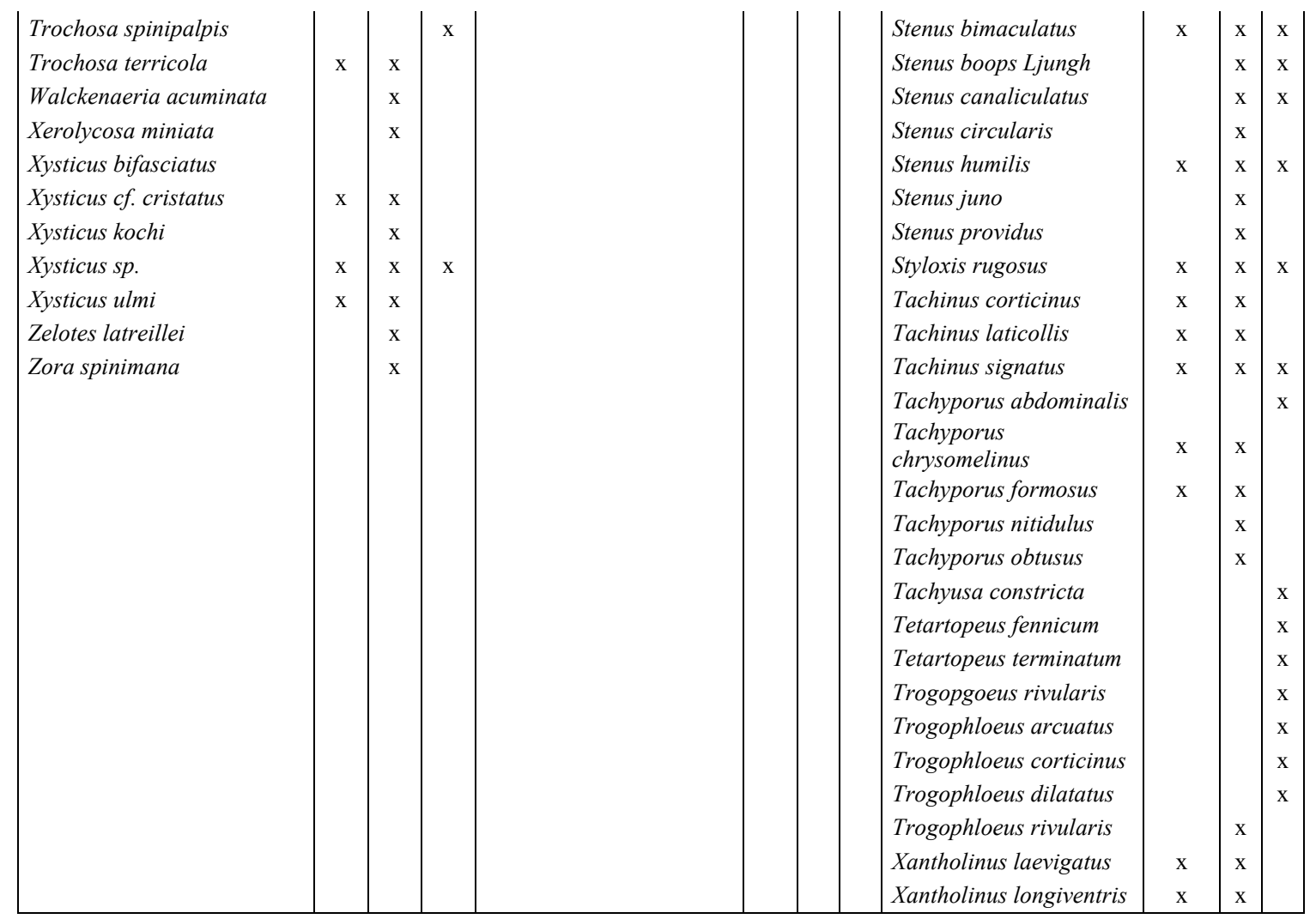

